been published, and readers can form their own opinions with regard to many of the charges contained in Mr. Green's letter. One further point, however, calls for a definite answer-his protest concerning the registration of the Faculty "during an interval between negotiations." This action was taken by the C.B.O. at a time when negotiations appeared finally to have broken down and after an overt threat by a representative of the A.B.O. that we should find there would be legal obstacles to the establishment of the Faculty.-

Mr. Green does not state whether he is expressing the considered opinions of the Council and Members of the A.B.O. or writing as an individual, I hope the latter, as I feel there must be many members of the A.B.O. who will be willing to co-operate in the establishment of the Faculty as a comprehensive body fully representative of all British ophthalmologists.

Yours faithfulfy,

W. H. MCMULLEN.

Chairman of Organising Committee of Faculty of Ophthalmologists.

\title{
PLASTIC SPHERES
}

To the Editors of The British Journal of Ophthalmology.

DEAR SiRs,-The article on plastic spheres by Major R. E. Wright, C.I.E., in the Brit. Jl. of Ophthal., November, 1944, will be read with considerable interest by ophthalmologists of the Central Mediterranean Forces.

- Perspex globes of $12-16 \mathrm{~mm}$. have been used by them for Tenon implantation for some months and are now an issue. At first, an R.A.F. Maintenance Unit kindly made them from scrap turret ribs, but now they are manufactured by the ever co-operative R.E.M.E.

So far as I am aware, 'no undue tissue reactions have occurred and excellent cosmetic results have been seen. Movement up, in, and down is generally good, but limited outwards.

We can thoroughly endorse the points of technique which Major Wright stresses. namely, a neat flat suture line and a reform prosthesis.

It is also found that an implant socket heals more readily than one following an ordinary enucleation, and that an artificial eye is well tolerated a fortnight after operation; this is of importance in military practice.

Delayed implants into recent clean sockets have been made with good results. 
The next series of Perspex -balls will be made with perforations as Major Wright suggests ; at present they have a rough or smooth finish.

We also provide Perspex artificial eyes for awkward sockets, but our experience in this line is not equal to that of the M.E.F. where the practice has been in vogue for some time with very satisfactory results.

Yours faithfully,

B. W. RYCROFT.

December 27, 1944

\section{PHLYCTENULAR OPHTHALMIA}

To the Editors of THE BRItish JOURNal of Ophthalmology.

DEAR SIRS,- - The discussion taking place on phlyctenular ophthalmia is to those of. us who live in Southern Australia very interesting.

If tubercule be the cause as some seem to think, the unhappy increase of tubercule recently in Victoria should be accompanied by an increase of phlyctenular ophthalmia. This condition long since was common. Now it is a rarity. I have not seen or heard of more than an odd case. I regarded it always as a deficiency disease, usually lack of protein. On a good diet it disappeared. Like trachoma in this part of Australia, it is a disappearing disease. Unhappily tubercule has since shown lately an increase, but so far as I can make-out phlyctenular ophthalmia has not increased as one would have expected if tubercule was the cause.

I make no suggestion regarding the considerable amount of investigation which is and has been conducted, but simply state the facts as set out. The disappearance of trachoma is likewise a - puzzle. It all points to a complex of causes difficult to unravel.

I have consulted many colleagues and the Ophthalmological Society, none of whom have seen any cases. But a physician who deals extensively in tuberculous diseases said he had seen one case in a tuberculous patient. Such are the facts as known to me.

Sincerely yours,

JAMES W. BARRETT.

MELBOURNE,

November 11, 1944. 